\title{
PENGARUH PEMBERIAN AKTIVITAS LEISURE TERHADAP TINGKAT KUALITAS HIDUP PASIEN PASCA STROKE
}

\author{
Wawan Ridwan Mutaqin, Ninik Nurhidayah \\ Kementerian Kesehatan Politeknik Kesehatan Surakarta Jurusan Okupasi Terapi
}

\begin{abstract}
Abstrack : Leisure Activities, Quality Of Life, Stroke. Stroke can cause impairment, disabilities and handicap so that patients will have difficulty in performing daily life activities, including self-care, productivity and leisure. It will cause decrease the patient quality of life. This study aims to determine the effect of leisure activities on the quality of life of Post-Stroke Patients. This study is an experiment with methods of the one group pretest-posttest design. Sampling was done by purposive sampling, with the number of samples of 25 stroke patients, at Ngemplak Boyolali District. The results showed that there was a possibility of the activity of leisure activity on the quality of life Post Stroke, significantly with the value of $p=0,002$ (physical health), $p=0,001$ (psychological), $p=$ 0,001 (social relation), and $p=0,000$ (environment). Based on age, the number of respondents is the final elderly of 11 people (44\%), male sex is 16 people (64\%), marital status 20 people (80\%) married / have spouse, most respondents are 8 people 32\%) did not work, and large respondents suffered stroke over 24 months as many as 10 people (40\%). The implication of this research is that leisure activities can be used as an alternative method in the treatment of occupational therapy in stroke patients.
\end{abstract}

Keywords: Leisure Activities, Quality Of Life, Stroke.

Abstrak: Aktivitas Leisure, Kualitas Hidup, Stroke. Stroke dapat menimbulkan impairmen, disabilitas dan hendaya sehingga penderita akan mengalami kesulitan dalam melakukan aktivitas kehidupan sehari-harinya, meliputi perawatan diri, produktifitas dan pemanfaatan waktu luang. Hal ini dapat menurunkan kualitas hidup penderita. Penelitian ini berjudul Pengaruh pemberian aktivitas pemanfaatan waktu luang terhadap kualitas hidup Pasien Pasca Stroke. Penelitian ini termasuk penelitian eksperimen dengan metode pretestposttest design bertujuan untuk mengetahui pengaruh pemberian aktivitas leisure terhadap kualitas hidup pasien pasca stroke. Pengambilan sampel dilakukan dengan purposive sampling, dengan jumlah sampel 25 pasien stroke, di Kecamatan Ngemplak Kabupaten Boyolali. Hasil penelitian menunjukkan bahwa terdapat pengaruh pemberian Aktivitas pemanfaatan waktu luang terhadap kualitas hidup Pasien Pasca Stroke secara signifikan dengan nilai $\mathrm{p}=0,002$ (kesehatan fisik), $\mathrm{p}=0,001$ (psikologis), $\mathrm{p}=0,001$ (hubungan sosial), dan $\mathrm{p}=0,000$ (lingkungan). Berdasarkan usia, mayoritas responden adalah lansia akhir sebanyak 11 orang (44\%), jenis kelamin mayoritas laki-laki yaitu 16 orang (64\%), status perkawinan mayoritas 20 orang $(80 \%)$ kawin/punya pasangan, sebagian besar responden yaitu 8 orang $(32 \%)$ tidak bekerja, dan mayoritas responden lama menderita stroke lebih dari 24 bulan sebanyak 10 orang (40\%). Implikasi penelitian ini bahwa aktivitas leisure dapat digunakan sebagai alternatif metode dalam intervensi okupasi terapi pada pasien stroke.

Kata Kunci: Aktivitas Leisure, Kualitas Hidup, Stroke. 


\section{PENDAHULUAN}

Stroke mengacu pada gangguan neurologik mendadak yang terjadi akibat pembatasan atau terhentinya aliran darah melalui sistem suplai arteri otak (Price dan Wilson, 2006). Gangguan neurologik ini sering terjadi secara mendadak (akut) dan tidak jarang menyebabkan kematian. Secara sederhana stroke dapat digambarkan sebagai cedera mendadak dan berat pada pembuluh-pembuluh darah (vaskuler) otak. Cedera ini dapat disebabkan oleh sumbatan bekuan darah, penyempitan pembuluh darah, atau pecahnya pembuluh darah (WHO, 2013).

Penyakit stroke telah menjadi masalah kesehatan yang dapat mengganggu kualitas hidup dan menjadi penyebab utama kecacatan pada usia dewasa. Stroke menduduki urutan ketiga sebagai penyebab utama kematian setelah penyakit jantung koroner dan kanker di negara-negara berkembang dan banyak menyerang pada usia produktif. Terdapat sekitar 13 juta korban stroke baru setiap tahun, dimana sekitar 4,4 juta diantaranya meninggal dalam 12 bulan (WHO, 2006).

Berdasarkan data yang dirilis oleh Yayasan Stroke Indonesia (Yastroki) sungguh membuat kita khawatir. Dinyatakan bahwa kasus stroke di Indonesia menunjukkan kecenderungan terus meningkat dari tahun ke tahun. Yastroki pada tahun 2007 menyebutkan bahwa 63,52 per 100.000 penduduk Indonesia berumur di atas 65 tahun ditaksir menderita stroke. Bahkan saat ini Indonesia merupakan negara dengan jumlah penderita stroke terbesar di Asia, karena berbagai sebab selain penyakit degeneratif, dan terbanyak karena stres (Hernowo, 2007). Pada 2020 mendatang diperkirakan 7,6 juta orang akan meninggal karena stroke. Tidak hanya di
Indonesia, konferensi Stroke Internasional yang diadakan di Wina, Austria, tahun 2008 mengungkap terus meningkatnya kasus stroke di kawasan asia akibat berubahnya gaya hidup masyarakat (Asosiasi Herbalis Nusantara, 2011).

Riskesdas tahun 2013

menyebutkan bahwa prevalensi stroke terdiagnosis nakes tertinggi di Sulawesi Utara $(10,8 \%$ ), diikuti DI Yogyakarta $(10,3 \%)$, Bangka Belitung dan DKI Jakarta masing-masing 9,7 permil. Prevalensi Stroke berdasarkan terdiagnosis nakes dan gejala tertinggi terdapat di Sulawesi Selatan (17,9\%o), diikuti DI Yogyakarta (16,9\%o), Sulawesi Tengah (16,6\%), Jawa Timur sebesar 16 permil, Sulawesi Utara $(14,9 \%)$, DKI Jakarta dan Bangka Belitung (14,6\%o), Kalimantan Selatan (14,5\%o), serta Jawa Tengah dan Gorontalo (12,3\%). Di Jawa Tengah sendiri, stroke merupakan penyakit dengan prevalensi tertinggi di Kabupaten Kota Boyolali, Semarang dan Salatiga.

Stroke dapat menimbulkan kecacatan yang meliputi impairment, disability dan handicap (Gullickson, 1981). Menurut Kaplan (1998), angka kecacatan stroke sekitar 50-60\% dan lebih kurang $1 / 5-1 / 3$ pasca stroke mengalami kecacatan menahun. Menurut Indrawan (2012), sekitar 70\% penderita pasca stroke memiliki disabilitas permanen secara okupasional, dan sekitar $25 \%$ akan mengalami demensia vaskuler. Hasil penelitian di Amerika menunjukkan bahwa dari 494 pasien stroke setelah 6 bulan menderita stroke, $47 \%$ mengalami ketergantungan penuh, 9\% mengalami ketergantungan dan 44\% ketergantungan sebagian (Trombly, 1989).

Sebagian penderita pasca stroke bahkan tidak dapat melakukan pekerjaan 
seperti biasa. Umumnya stroke berlanjut dengan depresi, dimana penderita sadar bahwa kondisinya sudah berubah, tidak lagi dapat melakukan hal yang biasanya secara rutin dilakukan sendiri, seperti makan harus disuapi, jalan menjadi lambat, dan mandi harus dibantu. Mereka jadi tenggelam dalam depresi dan menjadi sering menangis dan melamun.

Kondisi-kondisi tersebut mengakibatkan turunnya harga diri dan meningkatkan stres. Kondisi ini dirasakan sebagai suatu bentuk kekecewaan atau krisis yang dialami oleh penderita. Penderita merasa kehilangan tujuan hidupnya, merasa jauh dengan temanteman, dan kehilangan kesehatan fisik secara menyeluruh. Hal ini menimbulkan ketegangan, kecemasan, frustasi dalam menghadapi hari esok. Tekanan-tekanan tersebut biasanya mengganggu proses pengobatan secara medis maupun psikologis, sehingga akan semakin tinggi pula resiko psikologis yang dihadapi oleh penderita. Dampak yang muncul adalah penderita mengalami kesulitan atau bahkan tidak mampu melakukan aktivitasnya sehari-hari, meliputi self care (perawatan diri), productivity (produktivitas), dan leisure (waktu luang).

Dalam aktivitas perawatan diri, penderita kesulitan melakukan aktivitas, makan, minum, berpakaian, mandi dan lain-lain. Untuk produktivitas, penderita tidak dapat bekerja kembali. Dalam aktivitas leisure, penderita kurang mempunyai inisiatif/ kemauan melakukan aktivitas leisure, kesulitan mengungkapkan aktivitas leisure yang mau dilakukan, ketidakmampuan menilai makna aktivitas leisure dan melakukan aktivitas leisure. Penderita cenderung diam, duduk-duduk di rumah tanpa melakukan aktivitas (Trombly \&
Radomsky, 2008). Menurut Gillen, dkk. dalam Clare O'Sullivan dan Gill Chard (2010), setelah stroke, banyak orang memiliki tingkat penurunan signifikan partisipasi dalam kegiatan leisure. Semua ini berujung pada menurunnya kinerja okupasi (occupational performance) penderita. Oleh karena itu dibutuhkan upaya pemulihan/rehabilitasi insan pasca stroke agar mampu mandiri dalam melakukan aktivitasnya sehari-hari.

Okupasi Terapis mempunyai peran yang sangat penting pada penanganan pasien pasca stroke. Pelayanan okupasi terapis bertujuan untuk meningkatkan kemandirian dan mengembalikan peran pasien pada aktivitas kehidupan sehariharinya self care, productivity dan leisure (Trombly, 2002).

Aktivitas leisure merupakan aktivitas yang jarang dilakukan pada proses intervensi pasien. Padahal Drummond (1997), mengatakan bahwa peran okupasi terapi dan leisure pasca stroke menunjukkan bahwa individu belum tentu melanjutkan hidup penuh bahkan jika mereka memiliki pemulihan fisik yang baik. Pasien terbatas partisipasinya dalam aktivitas leisure dan kegiatan sosial.

Kabupaten Boyolali termasuk salah satu area dengan prevalensi stroke tinggi dan terus meningkat dari tehun ke tahun. Data awal menunjukkan bahwa pada tahun 2013, terdapat 1174 pasien terdiagnosa stroke (Data Rekam Medis RS Pandanarang, 2013). Banyaknya kasus stroke yang terjadi, memberikan dampak meningkatnya pelayanan kesehatan oleh pemerintah Kabupaten Boyolali.

Temuan studi Norwegia, mengatakan bahwa ada hubungan linear yang signifikan antara kepuasan hidup dan keterlibatan dalam kegiatan/aktivitas, 
bahkan tingkat keterlibatan dalam aktivitas waktu luang ternyata prediktor independen utama kesejahteraan (Sveen, et al., 2004). Adanya keterlibatan pasien stroke dalam aktivitas leisure dapat meningkatkan kualitas hidup pasien pasca stroke.

\section{METODE PENELITIAN}

Penelitian ini merupakan penelitian kuantitatif rancangan eksperimen pretest-posttest design without control group. Populasi dalam penelitian adalah semua pasien stroke di Kecamatan Ngemplak Kabupaten Boyolali. Pengambilan sampel menggunakan teknik purposive sampling, jumlah sampel 25 responden dengan kriteria sampel: 1). pasien pasca stroke yang mendapatkan pelayanan di Puskesmas Ngemplak, 2). tidak mengalami gangguan kognitif, 3). terdapat gerak aktif lengan pada sisi yang lemah (hemiparesis), dan 4). dapat memahami instruksi. Analisis data dilakukan melalui Uji Wilcoxon rank.

\section{HASIL PENELITIAN}

\section{Karakteristik Responden}

Karakteristik responden berdasarkan usia, jenis kelamin, status perkawinan, lama menderita stroke, dan pekerjaan adalah sebagai berikut:

\section{Tabel 1}

Karakteristik Responden Berdasarkan

\begin{tabular}{lcc}
\multicolumn{3}{c}{ Usia } \\
\hline Usia & Jumlah & Prosentase \\
\hline Lansia awal & 5 & 20 \\
Lansia akhir & 11 & 44 \\
Manula & 9 & 36 \\
Total & 25 & 100 \\
\hline \multicolumn{1}{c}{ Berdasarkan } & usia, & sebagian besar
\end{tabular}

responden masuk dalam kategori lansia akhir berjumlah 11 orang (44\%).
Tabel 2

Karakteristik Responden Berdasarkan Jenis Kelamin

\begin{tabular}{|c|c|c|}
\hline Jenis kelamin & Jumlah & Prosentase \\
\hline Perempuan & 9 & 36 \\
\hline Laki-laki & 16 & 64 \\
\hline Total & 25 & 100 \\
\hline
\end{tabular}

Tabel 3

Karakteristik Responden Berdasarkan Status Perkawinan

\begin{tabular}{lccc}
\hline Status Perkawinan & Jumlah & Prosentase \\
\hline Kawin & & 20 & 80 \\
Tidak kawin & 5 & 20 \\
& Total & 25 & 100 \\
\hline
\end{tabular}

Berdasarkan status perkawinan, sebagian besar responden masih menikah/punya pasangan berjumlah 20 orang (80\%).

Tabel 4

Karakteristik Responden Berdasarkan Lama Menderita Stroke

\begin{tabular}{|c|c|c|}
\hline Lama menderita & Jumlah & Prosentase \\
\hline$<6$ bulan & 2 & 8 \\
\hline $6-<12$ bulan & 5 & 20 \\
\hline $12-<24$ bulan & 8 & 32 \\
\hline$>24$ bulan & 10 & 40 \\
\hline Total & 25 & 100 \\
\hline
\end{tabular}

Berdasarkan lama menderita, sebagian besar responden lebih dari 24 bulan berjumlah 10 orang (40\%).

Tabel 5

Karakteristik Responden Berdasarkan Pekerjaan

\begin{tabular}{|c|c|c|}
\hline Jenis pekerjaan & Jumlah & Prosentase \\
\hline Tidak bekerja & 8 & 32 \\
\hline Tani & 5 & 20 \\
\hline Wiraswasta & 3 & 12 \\
\hline PNS & 1 & 4 \\
\hline Pensiunan & 4 & 16 \\
\hline Ibu rumah tangga & 4 & 16 \\
\hline Total & 25 & 100 \\
\hline
\end{tabular}


Berdasarkan jenis pekerjaan, sebagian besar responden tidak bekerja berjumlah 8 orang (32\%).

\section{Deskripsi Kualitas Hidup}

a. Tingkat Kualitas hidup sebelum intervensi

Berdasarkan tabel 6 diketahui bahwa sebelum intervensi, sebagian besar kualitas hidup dan kesehatan umum buruk/tidak memuaskan dan biasa-biasa saja (masing-masing 11 orang atau 44\%), kesehatan fisik sebagian besar biasa-biasa saja (12 orang atau 48\%), psikologi sebagaian besar responden merasa biasabiasa saja (13 orang atau 52\%), hubungan social sebagaian besar responden merasakan sangat buruk san buruk (masing-masing 9 orang atau $36 \%$ ), dan lingkungan sebagian besar responden merasakan buruk (13 0rang atau 52\%).

\section{Tabel 6}

Tingkat Kualitas Hidup Sebelum Intervensi

\begin{tabular}{lcccccccc}
\multicolumn{1}{c}{ Intervensi } \\
$\begin{array}{l}\text { Kualitas } \\
\text { hidup }\end{array}$ & $\begin{array}{c}\text { Sangat } \\
\text { buruk }\end{array}$ & Buruk & $\begin{array}{c}\text { Biasa- } \\
\text { biasa } \\
\text { saja }\end{array}$ & Baik & & m \\
\hline Kualitas & 2 & $8 \%$ & 11 & 44 & 11 & 44 & 1 & 4 \\
hidup dan \\
kesahatan & & & & $\%$ & & $\%$ & & $\%$ \\
umum & & & & & & & & \\
Kesehata & 2 & $8 \%$ & 9 & 36 & 12 & 48 & 2 & 8 \\
n fisik & & & & $\%$ & & $\%$ & & $\%$ \\
Psikologi & 4 & 16 & 7 & 28 & 13 & 52 & 1 & 4 \\
& & $\%$ & & $\%$ & & $\%$ & & $\%$ \\
Hubunga & 9 & 36 & 9 & 36 & 7 & 28 & - & - \\
n sosial & & $\%$ & & $\%$ & & $\%$ & & \\
Lingkung & 1 & $4 \%$ & 13 & 52 & 11 & 44 & - & - \\
an & & & & $\%$ & & $\%$ & & \\
\hline
\end{tabular}

b. Tingkat Kualitas hidup sesudah intervensi

Tingkat kualitas hidup sesudah intervensi dapat dilihat pada tabel 7 .
Tabel 7

Tingkat Kualitas Hidup Sesudah Intervensi

\begin{tabular}{lcccccccccc}
\hline $\begin{array}{l}\text { Kualitas } \\
\text { hidup }\end{array}$ & $\begin{array}{c}\text { Sangat } \\
\text { buruk }\end{array}$ & Buruk & \multicolumn{2}{c}{$\begin{array}{c}\text { Biasa- } \\
\text { biasa saja }\end{array}$} & Baik & $\begin{array}{c}\text { Sangat } \\
\text { baik }\end{array}$ \\
\hline $\begin{array}{l}\text { Kualitas } \\
\text { hidup dan }\end{array}$ & - & - & 2 & $8 \%$ & 15 & 60 & 7 & 28 & 1 & $4 \%$ \\
kesahatan & & & & & & $\%$ & & $\%$ & & \\
umum & & & & & & & & & & \\
Kesehatan & - & - & 1 & $4 \%$ & 17 & 68 & 4 & 16 & 3 & 12 \\
fisik & & & & & & $\%$ & & $\%$ & & $\%$ \\
Psikologi & - & - & 1 & $4 \%$ & 12 & 48 & 1 & 48 & - & - \\
& & & & & & $\%$ & 2 & $\%$ & & - \\
Hubungan & - & - & 4 & 16 & 13 & 52 & 8 & 32 & - & - \\
sosial & & & & $\%$ & & $\%$ & & $\%$ & & - \\
Lingkungan & - & - & 4 & 16 & 17 & 68 & 4 & 16 & - & - \\
& & & & $\%$ & & $\%$ & & $\%$ & & \\
\hline
\end{tabular}

Berdasarkan tabel 7 diketahui bahwa sebelum intervensi, sebagian besar kualitas hidup dan kesehatan umum buruk/ tidak memuaskan dan biasa-biasa saja (masing-masing 11 orang atau 44\%), kesehatan fisik sebagian besar biasa-biasa saja (12 orang atau 48\%), psikologi sebagaian besar responden merasa biasabiasa saja (13 orang atau 52\%), hubungan social sebagaian besar responden merasakan sangat buruk san buruk (masing-masing 9 orang atau 36\%), dan lingkungan sebagian besar responden merasakan buruk (13 0rang atau 52\%).

\section{Perubahan Kualitas Hidup}

a. Perubahan kualitas hidup dan kesehatan umum

Perubahan kualitas hidup dilihat dari kualitas hidup dan kesehatan umum dapat dilihat pada tabel 8 . 
Tabel 8

Perubahan Kualitas Hidup Dan Kesehatan Umum Sebelum Dan Sesudah Intervensi

\begin{tabular}{|c|c|c|c|c|}
\hline & & $\mathbf{N}$ & $\begin{array}{l}\text { Mean } \\
\text { Rank }\end{array}$ & $\begin{array}{c}\text { Sum of } \\
\text { Ranks }\end{array}$ \\
\hline kualitas & Negative & $0^{\mathrm{a}}$ & .00 & .00 \\
\hline $\begin{array}{l}\text { hidup dan } \\
\text { kesahatan } \\
\text { umum }\end{array}$ & $\begin{array}{l}\text { Ranks } \\
\text { Positive } \\
\text { Ranks }\end{array}$ & $20^{\mathrm{b}}$ & 10.50 & 210.00 \\
\hline sesudah & Ties & $5^{c}$ & & \\
\hline $\begin{array}{l}\text { intervensi - } \\
\text { kualitas } \\
\text { hidup dan } \\
\text { kesahatan } \\
\text { umum } \\
\text { sebelum } \\
\text { intervensi }\end{array}$ & Total & 25 & & \\
\hline
\end{tabular}

a. kualitas hidup dan kesahatan umum sesudah intervensi < kualitas hidup dan kesahatan umum sebelum intervensi

b. kualitas hidup dan kesahatan umum sesudah intervensi > kualitas hidup dan kesahatan umum sebelum intervensi

c. kualitas hidup dan kesahatan umum sesudah intervensi $=$ kualitas hidup dan kesahatan umum sebelum intervensi

Berdasarkan tabel 8 diketahui bahwa dari 25 responden 20 data bertanda positif (ada peningkatan kualitas hidup dan kesahatan umum setelah pemberian treatmen) dan 5 data sama (ties) tidak terjadi perubahan kualitas hidup dan kesahatan umum.

b. Perubahan kesehatan fisik

Perubahan kualitas hidup dilihat dari kesehatan fisik dapat dilihat pada tabel 9.
Tabel 9

\section{Perubahan Kesehatan Fisik Sebelum} Dan Sesudah Intervensi

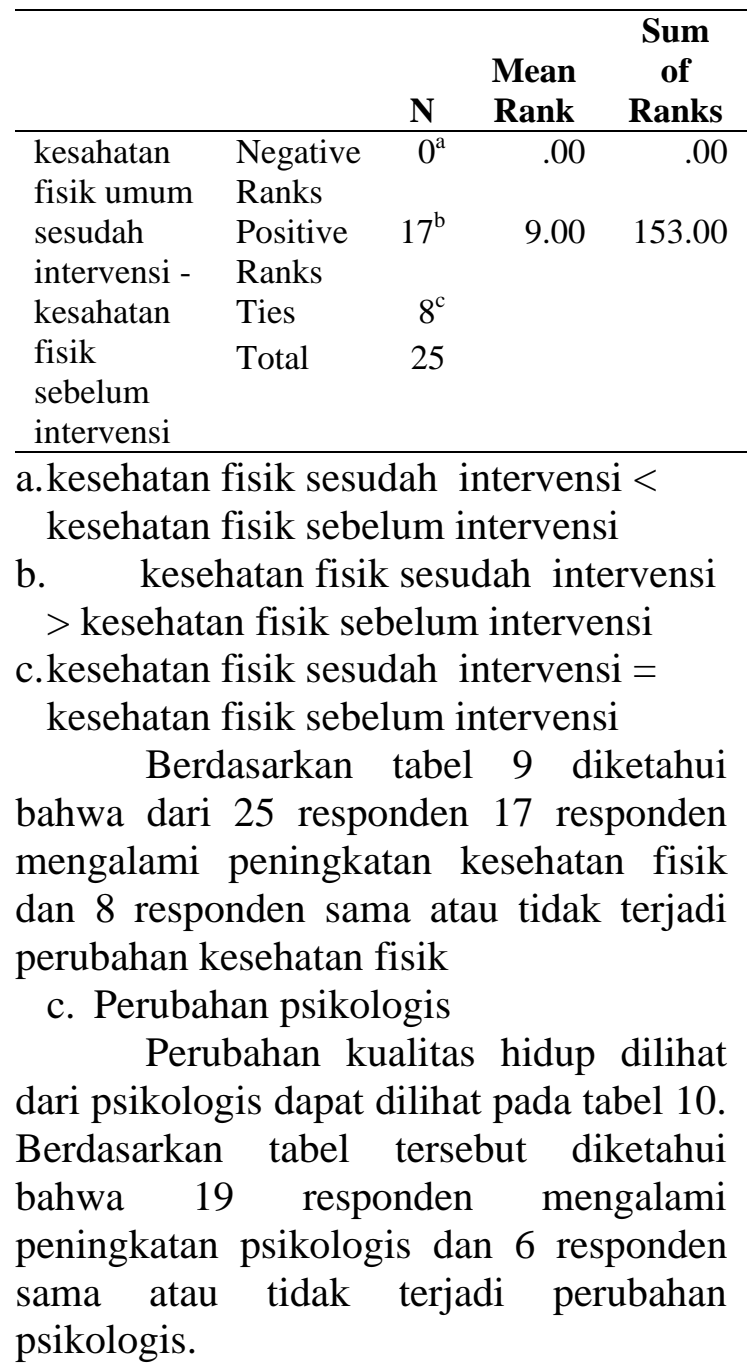

Tabel 10

Perubahan Psikologis Sebelum Dan Sesudah Intervensi

\begin{tabular}{llcrr}
\hline & N & $\begin{array}{r}\text { Mean } \\
\text { Rank }\end{array}$ & $\begin{array}{r}\text { Sum of } \\
\text { Ranks }\end{array}$ \\
\hline psikologis & $\begin{array}{l}\text { Negative } \\
\text { sesudah }\end{array}$ & $0^{\mathrm{a}}$ & .00 & .00 \\
intervensi - & Ranks & & & \\
psikologis & Ranks & $19^{\mathrm{b}}$ & 10.00 & 190.00 \\
sebelum & Ties & $6^{\mathrm{c}}$ & & \\
intervensi & Total & 25 & & \\
\hline
\end{tabular}


a.psikologis sesudah intervensi < psikologis sebelum intervensi

b. psikologis sesudah intervensi > psikologis sebelum intervensi

c.psikologis sesudah intervensi $=$ psikologis sebelum intervensi

d. Perubahan hubungan sosial

Perubahan kualitas hidup dilihat dari psikologis dapat dilihat pada tabel 11 .

\section{Tabel 11}

\section{Perubahan Hubungan Sosial Sebelum} Dan Sesudah Intervensi

\begin{tabular}{llcrr}
\hline & & \multicolumn{2}{c}{$\begin{array}{c}\text { Mean } \\
\text { Rank }\end{array}$} & $\begin{array}{r}\text { Sum of } \\
\text { Ranks }\end{array}$ \\
\hline $\begin{array}{l}\text { hubungan } \\
\text { sosial }\end{array}$ & $\begin{array}{l}\text { Negative } \\
\text { Ranks }\end{array}$ & $0^{\mathrm{a}}$ & .00 & .00 \\
$\begin{array}{l}\text { sesudah } \\
\text { intervensi - } \\
\text { hubungan }\end{array}$ & $\begin{array}{l}\text { Positive } \\
\text { Ranks }\end{array}$ & $23^{\mathrm{b}}$ & 12.00 & 276.00 \\
sosial & Ties & $2^{\mathrm{c}}$ & & \\
sebelum & Total & 25 & & \\
intervensi & & & & \\
\hline
\end{tabular}

a.hubungan sosial sesudah intervensi < hubungan sosial sebelum intervensi

b. hubungan sosial sesudah intervensi > hubungan sosial sebelum intervensi

c. hubungan sosial sesudah intervensi $=$ hubungan sosial sebelum intervensi

Berdasarkan tabel tersebut diketahui bahwa 23 responden mengalami peningkatan hubungan sosial dan 2 responden sama atau tidak terjadi perubahan hubungan sosial.

e. Perubahan lingkungan

Perubahan kualitas hidup dilihat dari perubahan lingkungan dapat dilihat pada tabel 12 .
Tabel 12

Perubahan Lingkungan Sebelum Dan Sesudah Intervensi

\begin{tabular}{llrrr}
\hline & & \multicolumn{2}{c}{$\begin{array}{r}\text { Mean } \\
\text { Rank }\end{array}$} & $\begin{array}{r}\text { Sum of } \\
\text { Ranks }\end{array}$ \\
\hline $\begin{array}{l}\text { lingkungan } \\
\text { sesudah }\end{array}$ & $\begin{array}{l}\text { Negative } \\
\text { Ranks }\end{array}$ & $0^{\mathrm{a}}$ & .00 & .00 \\
$\begin{array}{l}\text { intervensi - } \\
\text { lingkungan }\end{array}$ & $\begin{array}{l}\text { Positive } \\
\text { Ranks }\end{array}$ & $14^{\mathrm{b}}$ & 7.50 & 105.00 \\
umum & Ties & $11^{\mathrm{c}}$ & & \\
sebelum & Total & 25 & & \\
intervensi & & & & \\
\hline
\end{tabular}

a.lingkungan sesudah intervensi < lingkungan sebelum intervensi

b. lingkungan sesudah intervensi > lingkungan sebelum intervensi c. lingkungan sesudah intervensi $=$ lingkungan sebelum intervensi

Berdasarkan tabel 12 tersebut diketahui bahwa 14 responden mengalami peningkatan perubahan lingkungan dan 11 responden sama atau tidak terjadi perubahan lingkungan.

\section{Uji Normalitas}

Uji normalitas menggunakan Shapiro-Wilk test karena jumlah sampel kecil (25 sample).

\section{Tabel 13}

Hasil Uji Normalitas Data Dengan Shapiro-Wilk Test

\begin{tabular}{llrll}
\hline & & \multicolumn{3}{c}{ Kelompokiro-Wilk } \\
\cline { 3 - 5 } & Statistik & df & Sig. \\
\hline Kualitas hidup dan & Sebelum intervensi & .837 & 25 & .001 \\
kesehatan umum & Sesudah intervensi & .808 & 25 & .000 \\
\hline Kesehatan fisik & Sebelum intervensi & .856 & 25 & .002 \\
& Sesudah intervensi & .715 & 25 & .000 \\
\hline Psikologis & Sebelum intervensi & .820 & 25 & .000 \\
& Sesudah intervensi & .728 & 25 & .000 \\
\hline Hubungan sosial & Sebelum intervensi & .801 & 25 & .000 \\
& Sesudah intervensi & .800 & 25 & .000 \\
\hline Lingkungan & Sebelum intervensi & .731 & 25 & .000 \\
& Sesudah intervensi & .747 & 25 & .000 \\
\hline \multicolumn{2}{c}{ Berdasarkan tabel } & 13 & \multicolumn{3}{c}{ diketahui }
\end{tabular}

bahwa tingkat signifikansi semua item data berdistribusi tidak normal $(\mathrm{p}<0,05)$, 
maka uji statistik untuk menjawab hipotesis adalah mengunakan Wilcoxon Rank Test.

\section{Uji Hipotesis}

Hasil uji hipotesis dengan Wilcoxon Rank Test hasilnya sebagai berikut:

Tabel 14

Hasil Uji Wilcoxon Rank

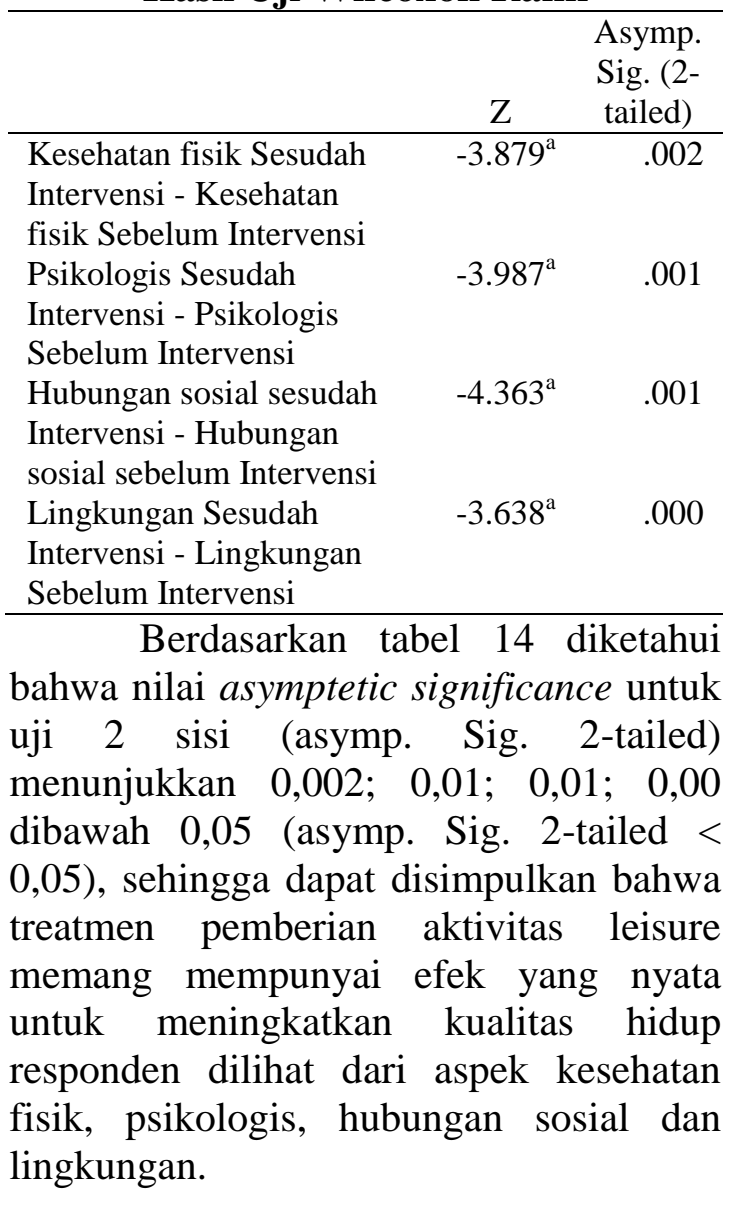

\section{PEMBAHASAN}

Berdasarkan hasil penelitian diketahui bahwa terdapat pengaruh pemberian aktivitas leisure terhadap kualitas hidup pasien pasca stroke. Hasil penelitian ini sesuai dengan penelitian yang dilakukan oleh Clare O'Sullivan and Gill Chard (2010) dengan judul An exploration of participation in leisure activities post-stroke, didapatkan hasil bahwa diperoleh empat tema muncul pada pasien stroke, yaitu (a) keterlibatan kembali dalam kegiatan leisure, (b) penerimaan keterbatasan fisik pasca stroke, (c) rasa terima kasih atas bantuan dan dukungan, serta (d) menatap masa depan.

Hasil penelitian Morgan, Debra \& Jongbloed (1990) dengan judul Factors Influencing Leisure Activities Following a Stroke: An Exploratory Study, diperoleh hasil bahwa usia mempengaruhi jenis kegiatan dimana orang menemukan kebermaknaan. Orang tua lebih menerima cacat pada teman-teman mereka. Standar pribadi, berbagai kepentingan dan akses ke transportasi juga mempengaruhi keterlibatan dalam sosial dan aktivitas leisure. Beberapa perubahan aktivitas, disebabkan hilangnya fisik dan fungsi mental. Namun interaksi individu dengan total lingkungan mereka jauh lebih penting daripada beratnya kecacatan. Kualitas hubungan individual dengan keluarga dan teman-teman adalah faktor yang paling berpengaruh menentukan kegiatan sosial dan rekreasi/leisure setelah stroke.

Begitu juga dengan hasil penelitian Heidi Janssen, Louise Ada, Julie Bernhardt, Patrick McElduff, Michael Pollack, Michael Nilsson, \& Neil J. Spratt (2014), dengan judul An enriched environment increases activity in stroke patients undergoing rehabilitation in a mixed rehabilitation unit: a pilot nonrandomized controlled trial, diperoleh hasil bahwa Pasien stroke yang diperkaya lingkungannya (enrichment environment), 1,2 kali lebih mungkin untuk terlibat dalam aktivitas apapun dibandingkan dengan orang-orang di lingkungan nondiperkaya. Mereka 1,7 kali lebih mungkin 
terlibat dalam kegiatan kognitif, 1,2 kali lebih mungkin untuk terlibat dalam kegiatan sosial, 0,7 kali lebih mungkin untuk menjadi aktif dan sendirian, serta 0,5 kali lebih mungkin untuk tertidur daripada pasien tanpa pengayaan. Penelitian ini merupakan penelitian awal yang menekankan bahwa model komprehensif pengayaan dikembangkan untuk digunakan dalam unit rehabilitasi, efektif dalam meningkatkan aktivitas pada pasien stroke dan mengurangi waktu yang dihabiskan tidak aktif dan sendirian.

Hasil penelitian Lucy-Ann Kubina, Claire-Jehanne Dubouloz, Christopher G. Davis, Dorothy Kessler \& Mary Y. Egan (2013), dengan judul The process of re-engagement in personally valued activities during the two years following stroke, mengungkapkan bahwa praktek rehabilitasi yang membahas dan mendukung otonomi, hubungan sosial, pengambilan risiko, adaptasi dan harapan antara penderita stroke dapat membantu individu mendapatkan kembali nilai pribadi dalam kegiatan pasca-stroke. Inti dari penelitian ini bahwa keterlibatan dalam kegiatan seringkali dinilai sulit untuk orang-orang yang telah mengalami stroke. Sebuah pemahaman yang lebih dalam dari proses keterlibatan kembali dalam kegiatan dinilai secara pribadi akan membantu mereka merancang intervensi untuk mengatasi partisipasi pasca stroke.

Penelitian oleh Sarah Northcott and Katerina Hilari (2011) dengan judul Why do people lose their friends after a stroke, mengungkapkan bahwa alasan utama kehilangan teman adalah hilangnya kegiatan bersama, tingkat energi berkurang, cacat fisik, aphasia, tidak membantu tanggapan lain, hambatan lingkungan, dan mengubah keinginan sosial. Sebagian dari peserta yang paling mengalami hilangnya banyak teman adalah mereka yang menggambarkan perasaan bahwa mereka 'mendekati' pada diri mereka sendiri yang mengarah ke menarik diri dari kontak sosial dan preferensi baru untuk bertemu teman-teman dekat dan keluarga saja. Mereka dengan aphasia mengalami tanggapan negatif yang paling menyakitkan dari orang lain dan menemukan lebih sulit untuk mempertahankan teman-teman mereka kecuali mereka memiliki pola dukungan persahabatan kuat sebelum stroke. Faktorfaktor yang membantu untuk melindungi persahabatan termasuk: memiliki sejarah bersama, teman-teman yang menunjukkan perhatian, yang tinggal secara lokal, di mana persahabatan tidak berdasarkan aktivitas, dan di mana peserta memiliki 'teman' berdasarkan jaringan sosial sebelum stroke. Penelitian ini menekankan bahwa hubungan antara depresi dan kehilangan teman-teman post stroke, mendukung individu dalam mempertahankan jaringan sosial mungkin dapat menguntungkan. Intervensi efektif, namun, mungkin perlu mempertimbangkan tidak hanya dampak cacat fisik dan bahasa baru, tetapi juga mengubah keinginan sosial.

Begitu juga dengan hasil penelitian oleh Clare O'Connell, Aoife Cassidy, Desmond O'Neill, and Hilary Moss(2013), dengan judul The Aesthetic and Cultural Pursuits of Patients with Stroke mengungkapkan bahwa kegiatan bioskop, mendengarkan musik, menari, menghadiri drama atau musikal, dan berada di luar ruangan merupakan kegiatan populer. Banyak pasien menghentikan kegiatan ini setelah stroke, terutama karena masalah kesehatan dan tidak dapat diakses. Sebagian besar pasien 
menilai pentingnya seni dalam pengaturan perawatan kesehatan. Penelitian ini memberikan perspektif untuk pertama kalinya pada estetika dan kegiatan budaya pasien stroke sebelum stroke. Ini menggambarkan berbagai kegiatan budaya dan rekreasi dan penghentian pasca stroke ini. Ini mengungkapkan pasien merasa terbatas untuk memperoleh akses ke kegiatan rekreasi baik saat di rumah sakit dan pulang.

Menurut Giantz \& Richman (2001), keuntungan yang diperoleh dengan melakukan aktivitas leisure dapat dilihat dari psikososial dan fisik. Keuntungan psikososial, yang dapat diperoleh adalah: (1) meningkatkan rasa harga diri, (2) melepaskan permusuhan dan sifat agresif, (3) berbagi kontrol diri dan lingkungan, (4) pengalaman pilihan, (5) meningkatkan sosialisasi, mengembangkan kepemimpinan, (7) praktik dalam perilaku adaptif dan keterampilan koping, (8) meningkatkan attention span, (9) menyesuaikan rencana hidup, (10) meningkatkan toleransi kelompok dan orang lain, dan (11) pengalaman stimulasi intelektual. Sedangkan keuntungan fisik yang dapat diperoleh adalah: (1) meningkatkan sirkulasi, (2) memperbaiki motorik kasar, halus, bilateral, dan koordinasi mata tangan, (3) memberikan stimulasi vestibular, (4) memberikan stimulasi sensoris, (5) memperbaiki motor planning, (6) memperbaiki dan memelihara kemampuan persepsi, (7) memperbaiki dan memelihara keterampilan adaptif dan koping, (8) meningkatkan kekuatan, lingkup gerak sendi, dan toleransi fisik, (9) memperbaiki keseimbangan, serta (10) memberikan kesempatan untuk aktivitas bertahap.
Menurut Marthuranath (2004), dengan aktivitas leisure, penderita mampu berinteraksi dengan lingkungan sekitarnya bersama penderita lainnya atau orang orang terdekat, menjalankan hobi serta aktif dalam aktivitas kelompok. Aktivitas sosial merupakan kegiatan yang dilakukan bersama dengan masyarakat di lingkungan sekitar (Napitupulu, 2010). Menurut Yumi (2008) teori aktivitas atau kegiatan (activity theory) menyatakan bahwa penderita yang selalu aktif dan mengikuti banyak kegiatan sosial adalah penderita yang sukses. Sebagai makhluk sosial manusia selalu berinteraksi dengan manusia lainnya, makhluk yang mampu berpikir sebelum melakukan sesuatu. Dari proses berpikir muncul perilaku atau tindakan sosial. Ketika seseorang bertemu dengan orang lainnya, dimulailah suatu interaksi sosial. Seseorang dengan orang lainnya melakukan komunikasi baik secara lisan maupun isyarat, aktivitasaktivitas itu merupakan suatu bentuk interaksi sosial. Selain itu, fungsi keluarga adalah sebagai tempat saling bertukar antar anggota keluarga untuk memenuhi kebutuhan fisik dan emosional setiap individu. Adanya partisipasi keluarga dengan memberi dukungan yang positif, maka secara tidak langsung memberikan motivasi kepada pasien.

\section{KESIMPULAN DAN SARAN}

Berdasarkan hasil penelitian diketahui bahwa terdapat pengaruh pemberian aktivitas leisure terhadap kualitas hidup pasien pasca stroke, dengan nilai $\mathrm{p}=0,002$ (kesehatan fisik), $\mathrm{p}=0,001$ (psikologis), $\mathrm{p}=0,001$ (hubungan sosial), dan $\mathrm{p}=0,000$ (lingkungan). Penelitian ini dapat dijadikan bahan pertimbangan dalam memberikan intervensi kepada penderita dengan kondisi pasca stroke. 
Saran untuk peneliti, hendaknya dilakukan penelitian yang lebih luas dengan jumlah sampel yang lebih banyak dan berkaitan dengan variabel-variabel yang berkembang dengan pasca stroke. Peneliti diharapkan memperhatikan variabel pengganggu yang menyebabkan bias dalam penelitian. Dalam menjelaskan suatu alat ukur kepada responden sebaiknya dijelaskan menggunakan bahasa yang mudah dimengerti sehingga responden benar-benar memahami sehingga mudah dalam pengisian instrumen. Peran keluarga sangat diperlukan dalam memberi dorongan dan motivasi kepada pasien dalam terapi secara konsisten baik di posyandu maupun di rumah.

\section{DAFTAR RUJUKAN}

Badan Penelitian dan Pengembangan Kesehatan. 2013. Riset Kesehatan Dasar (Riskesdas) 2013. Kementrian Kesehatan Republik Indonesia.

Clare O'Connell, Aoife Cassidy, Desmond O'Neill, and Hilary Moss. 2013. The Aesthetic and Cultural Pursuits of Patients with Stroke. National Stroke Association

Gillen, G., Whyte, N. C. \& Supon, D. A. 2004. Leisure participation after stroke. In: G. Gillen \& A. Burkhardt (Eds.), Stroke rehabilitation. A function-based approach $\left(2^{\text {nd }}\right.$ ed., pp. 633-645). Missouri: Mosby.

Heidi Janssen, Louise Ada, Julie Bernhardt, Patrick McElduff, Michael Pollack, Michael Nilsson, \& Neil J. Spratt. 2014. An enriched environment increases activity in stroke patientsundergoing rehabilitation in a mixed rehabilitation unit: a pilot non-randomized controlled trial. Disabilily and Rehabilitation an International, MultidiciplinaryJournal, $\quad 2014$; 36(3): 255-262.

Indawan R. 2012. Depresi pasca stroke. Retrieved: 20 Desember 2012, dari http://www.rsstroke.com/berita.ph p?id berita $=2$. Diunduh 26 Juni 2014.

Kaplan \& Saddock. 1998. Brief dynamic psychotherapy and crisis intervention. Synopsis of Psychiatry. Baltimore

Lucy-Ann Kubina, Claire-Jehanne Dubouloz, Christopher G. Davis, Dorothy Kessler \& Mary Y. Egan. 2013. The process of reengagement in personally valued activities during the two years following stroke. Disability \& Rehabilitation

MultidiciplinaryJournal, 2013; 35(3): 236-243

Morgan, Debra \& Jongbloed, Lyn. 1990. Factors Influencing Leisure Activities Following a Stroke: An Exploratory Study. Canadian Journal of Occupational Therapy (CJOT).Vo1.57.No. 4 October 1990.Pangkahila, W. (2001). Seks yang Indah. Jakarta: Penerbit buku kompas.

Price, S. A., \& Wilson, L. M. 2005. Patofisiologi konsep klinis prosesproses penyakit (6 ed. Vol. 2). Jakarta: EGC.

Sarah Northcott \& Katerina Hilari. 2011. Why do people lose their friends after a stroke. International Journal of Language \& Communication Disorders, 
September-October 2011, VOL. 46 , NO. 5, 524-534

Sveen, U., Thommessen, B., BautzHolter, E., Bruun Wyller, T. \& Laake, K. 2004. Well-being and instrumental activities of daily living after stroke. Clinical Rehabilitation, 18, 267-274

Trombly, C. A. \& Radomsky M. V. 2002. Occupational therapy for physical dysfunction. (5 ed). Baltimore : Williams and Walkins.

Trombly, C. A. \& Radomsky. 2008. Stroke. Occupational Therapy for physical dysfunction. Baltimore : Williams \& Wilkins.

Trombly, C. A. 1989. Occupational therapy for physical dysfunction. $\left(3^{\text {rd }}\right.$ ed). Baltimore : Williams and Walkins

WHO. 2006. The World Health Organization Quality of Life (WHOqol-Bref) Indonesian Version

WHO. 2007. Global Burden of Stroke. Retrieved November 25, 2013 http://www.who.int 